\title{
Sociocultural Aspects of Transgender's Slang
}

\author{
Surana \\ Universitas Negeri Surabaya, Surabaya, Indonesia \\ surana@unesa.ac.id
}

\begin{abstract}
This study examines the sociocultural aspects of transgender's slang. Considering the current problems, the descriptive method was used to describe the results of this study. The object of this study is the various language used by the transgenders in their daily communication. The data were collected, categorized, analyzed, and the results were presented in the form of description along with the examples. Sociocultural aspects that exist in transgender's slang can be the sociological, sociolinguistics, as well as the cultural aspects of the slang emergence among transgenders. Sociological aspects include the use of slang among transgenders inclusively. Those aspects are the use of speech unit in the form of words, phrases, sentences, and discourses. Furthermore, the establishments of transgender's slang are as follows: the sounds game, permutation, a play, replacements, additions, acronyms, and analogies. While the cultural aspects include transgender's slang function within the culture among the society members, which for: humoring, bullying, unifying, and as a communication tool.
\end{abstract}

Keywords: waria; slang; transgender; socioculture

\section{INTRODUCTION}

Language as one element of the cultural formation also deserves to be paid careful attention; similarly, so does the language used by transgender. This language has its own uniqueness. This uniqueness is associated with some sociocultural aspects of it [1]. This language is often categorized as a variation of a language that is so-called slang [2].

Waria is a term in the society that has an extension of 'pria-wanita (man-woman)'. Waria is previously known by the term of wadam which has an extension of 'wanita adam (adam-ladies)'. From those two terms, it seems that the term waria survives until now to indicate men who behave and speak like a woman. Waria exists in every region. Waria is a part of the minority groups and organizations that possess organized activities. One example of those organized activities is an activity located in Yogyakarta. This activity is accommodated in an organization called IWAYO (Association of Waria Yogyakarta). Meanwhile, such groups also sociologically conducted in other regions. These organized activities within a certain organization are almost held in every region by their own organization's names.

As part of a language user community, waria has a language of its own, in addition to the language used for communication with the outside community members. The special language spoken amongst this waria commonly called as Cant. Cant is a kind of slang but it deliberately designed to conceal something to another group. However, in this study, the special language 'cant' will be replaced by the term 'slang' [3].

Slang is a nonstandard word that is informal and arranged arbitrarily. Perhaps, it also derives from a certain mispronounce; e.g. reversed language pronunciation. These words almost exist in every society layer and are applied by certain groups. Kinds of sociocultural aspects within the cultural element which arise in the form of slang among waria are the issue that will be discussed in this paper. Finally, the focus of this discussion is only on the cultural aspect alone.

\section{RESEARCH METHOD}

\section{A. Data}

In fact, the data is the target object along with its context. In this study, the object is the language variance used by the waria in their daily communication.

\section{B. Source}

The source can be divided into two categories (substantive or locational) based on its correlation. Substantive source (or usually known as a sample) is a set of discourse since it is quite representative and always chosen by the researchers. While the locational source is the speaker; the person who gives the data along with the substantive data and usually known as a resource person.

\section{Data context}

The data context is various discourses, sentences, and clauses which are used by the waria.

\section{The procedure of the study}

This study will be conducted in three steps including preparation, conducting, and finishing. This study is a descriptive study in which the object is the various language used by the waria in their daily communication. That waria are the members of IWAYO (Ikatan Waria Yogyakarta) based in Yogyakarta, Indonesia. The data were collected through recording, noting and tapping techniques. Then, the data were categorized and analyzed by using identity and distributional method. These methods used to find the sociocultural aspects of waria's slang. The results of this 
study were presented in the form of description along with the examples with no symbols.

\section{RESULTS AND DISCUSSION}

In this results and discussions, the sociocultural aspects of waria's slang covering cultural and functional aspects will be explained as follows:

\section{A. Sociocultural aspects}

Sociological aspects that influence the occurrence of slang among waria could come from outside or within the waria communities itself. For example, the influence from the outside, they generally require outside group recognition to be recognized as a separate community. They also want to be recognized for their existence and identity. For all of those achievements, they are trying to make it happen by doing activities such as 'the prettiest waria competition,' and doing sport along with other communities. Sociologically, those activities mentioned are committed to showing that they exist, and their existence is recognized by the outside group.

Otherwise, the intern influence of the slang occurrence derives from slang that is created by themselves in the use of communication between them. The sociolinguistic existence of this slang can be regarded as a part of a unique language.

Basically, in terms of shape, slang is not the language or dialect, but rather an expression or word [4] [5]. Meanwhile, based on its function, slang can relieve seriousness and is a social game. The same thing was said by [6] that slang only emerges to freshen the atmosphere and intimate relationship in a certain association. In addition, slang is often used as a symbol of solidarity and a speaker's membership to a social group or a particular group [7]. Slang expressions are quite aggressive, rude, wild, and low. Slang is also served to convey aggression, to create and maintain social position, and to show their maleness among men [5] [8].

Slang is sometimes interpreted as a nonstandard language used by a group with the intent to conceal something. On the other hand, in this paper, slang is interpreted as expressions included in the various nonstandard languages used by the certain social group, usually young people, by the aim that other groups know and understand what the slang is created for. In this study, slang is used by waria. Slang among waria can be a word, group of words, abbreviations or acronyms, a play, and so forth.

\section{Cultural Aspects: The Function of Slang among Waria}

Speaking people certainly have an intention in every their words, both related to the languages and words they choose. Likewise speaking people, waria also choose a visual means to express their intentions. Slang among waria is an option and it is raised to carry out certain functions.
Language created by this waria is anonymous so that there are no strict rules of the slang formation. The creators of waria language are bound in an association called Iwayo, especially for waria in Yogyakarta. This association is formed as a solidarity event for waria, as well as bonding to accommodate groups' needs/matters and activities of its members.

The routine of the waria is to meet twice a week (on every Wednesday dan Sunday) in the secretariat and field to practice sports and so forth. The daily routine of waria is working as hairstylists, singers, and a small portion of students in the afternoon. A profession in the barbershop is mostly occupied by waria during the day.

At night, waria is always gathering in a place that is usually used together respectively. Places that are commonly used as a platform to meet and to congregate at night are at Tugu station area, around Mandala Krida Stadium, Cik Di Tiro Street, North Square, and around Yogyakarta Malioboro (for Yogyakarta waria). The place is frequently visited by most of the waria is the left and right area of Tugu Station. In this place, dozens of waria always gather every day. This special place is also often used by prostitutes, especially in the area of Pasar Kembang Street.

Waria, as humankind, generally would require an interaction with others in order to fulfill all their needs. They also made contact with each other socially. Thus, waria can be as not only individual beings but also social beings even within a selective interaction.

The interaction that is often committed by the waria is being interacted only among waria itself. However, in their dating, waria only serve against the men for fun and a few gay. They do not want to date with a fellow waria, especially among women.

Interactions and social contacts made amongst them, waria have a distinctive language that is usually only understood by them alone (although in its development this limitation getting loose). This language is used other than to communicate well for cooperation. This language is specially created for the creativity of its members as well as an integral tool among members. From this description, it can be said that the language of waria, reviewed from its function, is a special secret language used to communicate among waria. Moreover, the functions of waria slang for them are as follow:

\section{B. Humor function}

The function of humor in slang among waria can be seen from the examples that are looked and sounded more interesting, as follows:

- mekong 'eat'

- mina 'drink'

- minang 'drinking alcohol' 
- teges 'three'

- seretong 'a hundred'

- mongta 'five hundred'

- serini 'a thousand'

- mongta retong 'a half million'

- sejetong 'a million'

- Endang S. Taurina 'very tasty'

- Farid Harja 'very bitter'

- kemande Anjas 'where have you been'

- Xanana Gusmao 'over there’

- ewonglah akika 'marry me'

- harum duta akika 'I do not have money'

- akika malaysia ah ngobras samsara diana

- 'I have no feeling to talk to her/him'

- matahari lo picek ye! Organda lagi tinjauan dibangunin. 'Blind eyes! You wake sleeping people up'

This function also dominates slang humor among waria. This function indeed proves that slang is now experiencing a shift function, in which used usually to keep secret among most of the waria; it has recently become the lingua franca, especially among young people.

1) Bullying functions. Function mocking the slang in waria area, among other things look at an example:

$$
\begin{aligned}
& \text { - } \quad \text { bawang 'bad smell' } \\
& \text { - } \quad \text { mabong pelong 'testicles' } \\
& \text { - } \quad \text { meong 'gambling' }
\end{aligned}
$$

From the example above, it can be expected that the function of slang among waria is to offend someone. For example, a person who has bad smell will be bullied using the word bawang which connotes the smell. Furthermore, a drunken person usually feels offended when they are called as a drunk, but when called them with mabar, with the same meaning, they will not be offended.

2) Communication functions. Clear communication functions appear amongst waria. The creation of this language cannot be separated from their demand to be able to communicate specifically with members of waria. This language also intended to keep things hidden that can only be known by his fellow members only. By creating this special language, they also want to show their identity that emerges differently than the other ordinary people.
3) Unifying functions. The unifying function of slang amongst waria can be seen at the perception and feeling of camaraderie with those who are willing and able to use the waria language. The use of that language is aimed to unite them with the solidarity of using the same language. Sociocultural language functions that can be performed by slang among waria include functionality to convey secret messages, jokes, bullying, and refine phrases that are considered taboo or that could cause embarrassment (euphemistic sense). In addition, slang often used as a symbol of solidarity and speakers membership to a certain social group or a particular spoken group.

\section{CONCLUSION}

Sociocultural aspects that exist in waria slang can be in the form of sociological, sociolinguistics, and cultural aspects of the slang created among waria. Sociological aspects include the use of inclusive slang among waria. Moreover, sociolinguistics aspects include the use of language units such as words, phrases, sentences, and discourses. After that, the waria slang can be created in these ways: the sounds game, permutation, a play, replacements, additions, acronyms, and analogies. Meanwhile, cultural aspects of waria slang include the functions of waria slang within cultural among society members are as follows: humoring, bullying, unifying, and communication functions.

\section{REFERENCES}

[1] Blount BG and Sanches M (Eds. ). Sociocultural dimensions of language change. 2014.

[2] Shivakumar S T. Aspects impeding affirmative practices and comparison of multi-dimensional gender/consciousness of transgenders Int. J. Psychol. 997. 2016.

[3] Rahayu SP. Slang dalam Bahasa Jawa, Analisis Kasus di Mal Malioboro Yogyakarta (Yogyakarta: Pasca Sarjana Universitas Gadjah Mada). 1996.

[4] Anderson L and Trudgill. Bad Language (Oxford: Basic Blackwell Ltd). 1990.

[5] Ediati A, Maharani N and Utari A. Sociocultural aspects of disorders of sex development. Birth Defects Research Part C: Embryo Today 4 380-3. 2016

[6] Spears R A. Slang and Euphemism (New York: Jonathan Davis Publishers Inc.) 1981.

[7] Purnama K. Slang Bahasa Melayu Brunei; Makalah untuk Simposium Internasional Ilmu-Ilmu Humaniora II Bidang Sejarah dan Linguistik (Yogyakarta). 1983.

[8] Poedjoedarmo S. Pengantar Sosiolinguistik (Yogyakarta: Laporan Penelitian UGM, Lembaga Kajian Kebudayaan). 1984. 